Research Article

\title{
Comparative Analysis of Drilling Behaviour of Synthetic and Natural Fiber-Based Composites
}

\author{
A. Mohan Kumar ${ }^{D},{ }^{1}$ R. Rajasekar ${ }^{D},{ }^{1}$ P. Manoj Kumar ${ }^{(D)}{ }^{2}$ R. Parameshwaran $(\mathbb{D}$, \\ Alagar Karthick ${ }^{3},{ }^{3}$ and M. Muhibbullah ${ }^{4}$ \\ ${ }^{1}$ School of Building and Mechanical Sciences, Kongu Engineering College, Perundurai 638060, Tamil Nadu, India \\ ${ }^{2}$ Department of Mechanical Engineering, KPR Institute of Engineering and Technology, Coimbatore 641407, Tamil Nadu, India \\ ${ }^{3}$ Department of Electrical and Electronics Engineering, KPR Institute of Engineering and Technology, Coimbatore 641407, \\ Tamil Nadu, India \\ ${ }^{4}$ Department of Electrical and Electronic Engineering, Bangladesh University, Dhaka 1207, Bangladesh
}

Correspondence should be addressed to M. Muhibbullah; m.muhibbullah@bu.edu.bd

Received 18 August 2021; Revised 5 October 2021; Accepted 6 October 2021; Published 21 October 2021

Academic Editor: Jinyang Xu

Copyright (c) 2021 A. Mohan Kumar et al. This is an open access article distributed under the Creative Commons Attribution License, which permits unrestricted use, distribution, and reproduction in any medium, provided the original work is properly cited.

\begin{abstract}
For comparison, the drilling behaviour of abaca fiber-reinforced polymer (AFRP) composites and Kevlar-reinforced epoxy polymer (KFRP) composites has been studied in the specified experimental condition. The different geometrical drilling tools have been used for the investigation, namely, candlestick (T1), core (T2), standard twist drill (T3), and step cone (T4). The tool feed of 30,45 , and $60 \mathrm{~m} / \mathrm{min}$ and rotational speed of 1000,1500 , and $2000 \mathrm{rpm}$ have been used for the investigation. The thrust force is chosen as a response parameter for this study. The results revealed that, at lesser rotational speed and tool feed, the thrust force has declined. The result obtained correlates with the abaca fiber-based systems. However, the thrust force of KFRP is higher compared to AFRP composite systems. The axial force generated by candlestick drill is minimal compared to the other drill bits. The following may be responsible for lower thrust force: (1) the axial force distributes circumferential of the cutting tool instead of focusing at the center and (2) the interfacial adhesiveness between the matrix and the fiber is higher. The optimization of drilling process parameters, namely, tool feed and rotational speed on thrust force, has been studied. The results reveal that the tool feed contributed more to axial force compared to rotational speed.
\end{abstract}

\section{Introduction}

The studies have revealed that drilling is quite essential in the final machining process in the assembly of components. Drilling in fiber-reinforced matrix composite is difficult owing to the anisotropic nature of materials. Nowadays, delamination-free hole in the fiber-based composite is a challenging task faced by researchers; it leads to thinking of alternate technology for the drilling process. Further, the applications of different geometrical drill bits, predrilled hole, supporting plate, and different unconventional drilling techniques are studied. The special drill portrays various intensities of axial force along with tool feed during the drilling process [1]. The geometrical drill bits, namely, saw, candlestick, core drills, and more, distributed thrust force circumferential of the hole instead of focusing on the center (twist drill) of hole. The backup plates in fiber-based composite protect hole walls from peel-up delamination [2]. The drilling in KFRP is analysed by standard and modified twist drill bit with negative point angle. It is reported that the tests are performed in cryogenic and ambient temperatures. The delamination is analysed by two methods, namely, the linear elastic fracture model and the three-dimensional finite element model. The results reveal that the drilling is done successfully in Kevlar-based composite by high-speed steel drill bit with negative point angle. Moreover, the effect of temperature during drilling generates delamination in the composite specimen [3]. The investigation on drilling is 
carried out in carbon-reinforced epoxy composite with three variables, drill diameter, tool feed, and spindle rotational speed. Three different drill tools, namely, saw, standard twist drill, and candlestick bits, have been employed for investigation. The delamination is measured by an ultrasonic C-Scanner machine. Results reveal that the tool feed and diameter of the drill contribute more to the overall performance of the drilling process. The saw and candlestick drill bits produce a lower thrust force compared to the twist drill bit $[4,5]$. The experimental analysis and finite element study of unidirectional glass fiber-based composite are done. The different angles such as $118^{\circ}, 104^{\circ}$, and $90^{\circ}$ are used in the twist drill bit. The results revealed that the point angle and feed rates influence thrust force more. The point angle of $90^{\circ}$ portrays better results compared to that of $118^{\circ}$ and $104^{\circ}$ [6].

The temperature field model for Kevlar-reinforced epoxy resin is developed using two techniques: homogeneous hypothesis of materials and finite difference method. The result shows that the temperature distribution is elliptical in shape from the drilling zone to the fiber orientation direction [7]. The experimentation and finite element analysis are done during drilling in glass fiber-reinforced epoxy composite. The results produced by finite element analysis correlate with the experimental results [8]. Glass fiberreinforced polymer composites to experimentation are subject to varying rotational speed and tool feed. The range of spindle speed and feed rate used for investigation is $1000-2500 \mathrm{rpm}$ and $100-400 \mathrm{~mm} / \mathrm{min}$, respectively. The digital image processing is used to measure delamination. The result reveals that, at a lower feed rate and higher spindle speed, the delamination is reduced. Further, with the increase in the spindle speed, the delamination is increased [9].

Critical feed rate and critical thrust force are predicted by the thermomechanical model. This new model includes the drilling parameters like point angle and chisel edge load. The result shows that the critical thrust force and critical feed rate reach the peak while increasing the chisel edge [10]. The thermal and mechanical responses of functional graded composite materials are compared with carbon- or glass-based composites. Drilling parameters such as thrust force, diameter of hole, delamination factor, and roundness during drilling operation are considered for experimental analysis. The drilling parameters and different drill bits are used in the conventional synthetic fiberbased composite [11]. The effect of cutting parameters on the delamination during drilling of glass layered aluminum reinforced epoxy composite (GLARE) is also studied. The result portrays that feed marks in aluminum laminae get increased and interlayer burrs are formed while the feed rate increases. A better surface finish is obtained while spindle speed increases. Two types of modern cooling technologies like cryogenic liquid nitrogen (LN2) and minimum quantity lubrication (MQL) are employed during drilling. The results show that drilling of glass aluminum-reinforced epoxy composite under MQL and LN2 generates different types of chip formation, interlayer burr formation, and fiber bending similar to dry drilling at ambient temperature [12]. Similarly, the influence of feed rate and spindle speed on thrust force is studied. The two dissimilar materials used are armor steel and glass fiberreinforced epoxy resin. The test specimen prepared by armor steel is placed between two glass fiber-reinforced polymer layers. The result reported that the thrust force required is more in bottom glass fiber-based composite plate owing to the part of drill occupied in the armor plate. The heat produced in the middle armor steel plate also is high due to thrust force generation [13]. The damage mechanisms during drilling are identified and categorized by signals emitted in acoustic tests. The glass fiber-reinforced epoxy composite is used as a test specimen. Matrix cracking, delamination, fiber pullout, and friction are categorized and frequency distributions are found for each of them [14]. The influence of drilling process parameters on delamination and tensile strength is studied. Bamboo/ Kevlar-based hybrid composite is used as a test specimen. The spindle speed and feed rate also are considered as drilling process parameters. The results reveal that the effect of feed rate is more on delamination and pulling strength compared to rotational speed. The Taguchi method-based ANOVA technique is employed for the optimization of drilling process parameters. The percentage of contribution of feed rate and spindle speed is $13.88 \%$ and $81.74 \%$, respectively [15].

Bajpai et al. [16] studied the hole-making characteristic of Sisal and Grewia optiva fiber-based composites. The effect of hole-making process parameters, namely, cutting speed, tool feed, and drill bit geometry, on axial force and torque has been investigated. It has been reported that the geometry of the drill influences more on thrust force during the drilling process. The glass, hemp, and sandwich fiberreinforced epoxy composites are used for the study of mechanical behaviour. The three levels of rotational speed, tool feed, and fiber volume fraction are engaged for experimental analysis. The outcomes reported that the greater cutting speed and minimal tool feed are suitable for damagefree drilling [17]. The influence of hole-making process parameters on tool wear torque and axial force during drilling of coir fiber-based composites is predicted by a mathematical model. It is suggested that the mathematical model can be used to find results during hole making in coir reinforced polymer composites within the limit of adaptable [18]. In order to decrease the number of experiments during experimentation by converging results into optimum value, the Taguchi method is suitable. The cutting speed and tool feed are used as input parameters in the Taguchi technique. The response parameter used is drill point angles of $118^{\circ}$ and $135^{\circ}$. The process parameters have four levels. L16 orthogonal array is utilized to decrease the experiment counts [19]. Further, the optimizations of drilling process parameters are optimized by adopting the Taguchi technique. The drilling process parameters like tool feed and rotational speed are employed for optimization. The axial force, surface coarseness, and layer debonding factors are chosen as response parameters. Taguchi's L16 is used for this experimental analysis [20]. The process variables considered, namely, drill rate, tool feed, and nose angle of the drill, are employed. The response parameters, burr height and surface roughness, are chosen for the study. Taguchi's L27 and three 
process parameters also are utilized for the experimental tests. The results reported that the low feed rate, minimum drill rate, and maximum nose angle of the drill might be suitable for generating less burr length and surface unevenness [21]. L18 and process parameters with four levels are chosen for optimization study. The process parameters are tool feed, cutting speed, and tool type used. The temperature measurements in the drill bit are chosen as response parameters for the study [22]. The optimization of input process variables of drilling on axial force and torque is found by using the Taguchi technique. Likewise, cutting speed, rotational speed, point angle, and chisel edge are selected as drilling process parameters. L9 orthogonal array and three levels of process parameters are chosen for the experimental study [23]. Thrust force and spindle speed have contributed equally towards reducing the thrust force [24]. The effect of input process parameters of drilling, namely, specimen thickness, tool feed, and drill rate, on delamination of glass fiber-based composites is studied. The results reveal the effect of sample thickness and drill rate more on the debonding at the exit and the influence of sample thickness and feed rate on the push-down delamination $[25,26]$.

\section{Materials and Methods}

The epoxy matrix has the density of $1.16 \mathrm{~g}$ and its viscosity and temperature are $900 \mathrm{cps}$ and $25^{\circ} \mathrm{C}$, respectively. The bidirectional Kevlar 49 woven fabric with $1 \mathrm{~m}^{2}$ was used for the fabrication of composite. Drilling experiments are done in the Makino S33 CNC machine. The investigational setup is shown in Figure 1, and the specification of the CNC machine is shown in Table 1.

2.1. Kevlar and Abaca. Kevlar fiber was discovered by Kwolek and Blades in DuPont's laboratory in 1965 [27]. It is a natural fiber in the aromatic polyamide family. It has a distinctive amalgamation of high strength, modulus, toughness, and thermal stability. It can be spun into ropes or woven fabric which can be used to make composite components. Kevlar is used for a broad range of applications starting from sports goods to body armor, owing to its high strength to weight ratio. In general, it is five times stronger than steel on an equal weight basis [27]. It is a member of the aramid family of synthetic fibers and a competitor of Twaron manufactured by Teijin [28]. Its pictorial view and structure are shown in Figures 2 and 3 , respectively.

In 1965, scientists at DuPont exposed a novel technique of generating perfect polymer chain extension.

In aramid fiber, the fiber-forming matter is a long-chain synthetic polyamide in which a minimum of $85 \%$ of the amide linkages is bonded directly to two aromatic rings. Most of the amide groups are directly linked to two aromatic rings [29]. Owing to their extremely aromatic and controlled structure, aramids comprise very high thermal stability. Among all composite materials, Kevlar fiber-based composites have higher specific strengths. Aramid fibers provide exceptional combinations of properties, namely, creep resistance, high specific strength, toughness, and reasonable cost for definite applications.
Abaca fiber is also called Musa textilis or Manila hemp, which is purchased from Go Green Products Company, located in Coimbatore district, Tamil Nadu, India.

2.2. Preparation of Composites. The Kevlar-reinforced epoxy composite specimen is made with 4 layers of $3 \mathrm{~mm}$ thickness. The Kevlar fibers are used in the form of woven fabric and fiber content is 30\% in vol.\% [30]. Epoxy resin is used as a matrix to prepare the composite specimen. The hand layup process and compression moulding method have been used to stacking and maintained uniform composite thickness, respectively. The abaca fibers with an average diameter of $0.02 \mathrm{~cm}$ are cleaned and chopped into the required length ranging from 27 to $32 \mathrm{~cm}$. Before making the composites, the fibers are dried at $60^{\circ} \mathrm{C}$ under vacuum for 2 hours in order to remove the moisture content [30].

2.3. The Drill Bits and Drilling Parameters. The carbide drill with a diameter of $6 \mathrm{~mm}$ has been used for the experimental investigation due to the minimal wear [31]. The thrust force and torque of KFRP and AFRP have been analysed in a specified experimental condition. The nomenclature of standard twist drill tools like point angle $\left(118^{\circ}\right)$, chisel edge, flute, and main cutting edge is shown in Figure 4(a). The core drill tool geometries having inner circle " $\mathrm{a}$ " and outer circle " $b$ " and abrasiveness on the periphery are shown in Figure 4(b). The geometries of the T1 drill bit that comprises interior cutting edge, external cutting edge, inner drill tip, outer drill tip, and tip included angle of $72^{\circ}$ are shown in Figure 4(c). It produces focused and circumferential forces during machining [32]. The nomenclature of the T4 drill bit that consists of tip included angle $\left(82^{\circ}\right)$ and diameter of drill that increases from $2 \mathrm{~mm}$ to $10 \mathrm{~mm}$ is shown in Figure 4(d) [33]. Four different geometries of drill tools used for the experiments are $\mathrm{T} 1, \mathrm{~T} 2, \mathrm{~T} 3$, and $\mathrm{T} 4$ [33]. The rotational speed, tool feed, and dill diameter chosen with three levels and four dissimilar geometries of special drill tools are displayed in Table 2. The combination of three ranges of rotational speed and tool feed is utilized to perform nine holes in the specimen.

\section{Results and Discussion}

3.1. The Influence of Different Drill Geometries on Axial Force during Drilling of KFRP Composite. This section comprises the optimization of process variables (rotational speed and tool feed), namely, thrust force and torque during drilling of Kevlar and abaca epoxy composites. The different geometries drill tools that have been utilized for the experimentation are T1, T2, T3, and T4 drill bits. Figure 5 reveals that the thrust force is generated as a consequence of standard T1, T2, T3, and T4 drill tools at different speeds and feeds reinforced. Figure 5 shows that the thrust force increases with the increase of the feed rate for all the drill bits. For $\mathrm{T} 1$ and at $1000 \mathrm{rpm}$, the thrust force increases $15.87 \%$ more at $45 \mathrm{~mm} / \mathrm{min}$ compared to the $30 \mathrm{~mm} / \mathrm{min}$ feed rate as shown in Figure 5(a). Similarly, the same trend is followed for T2 and at $1000 \mathrm{rpm}$; the thrust force rises 


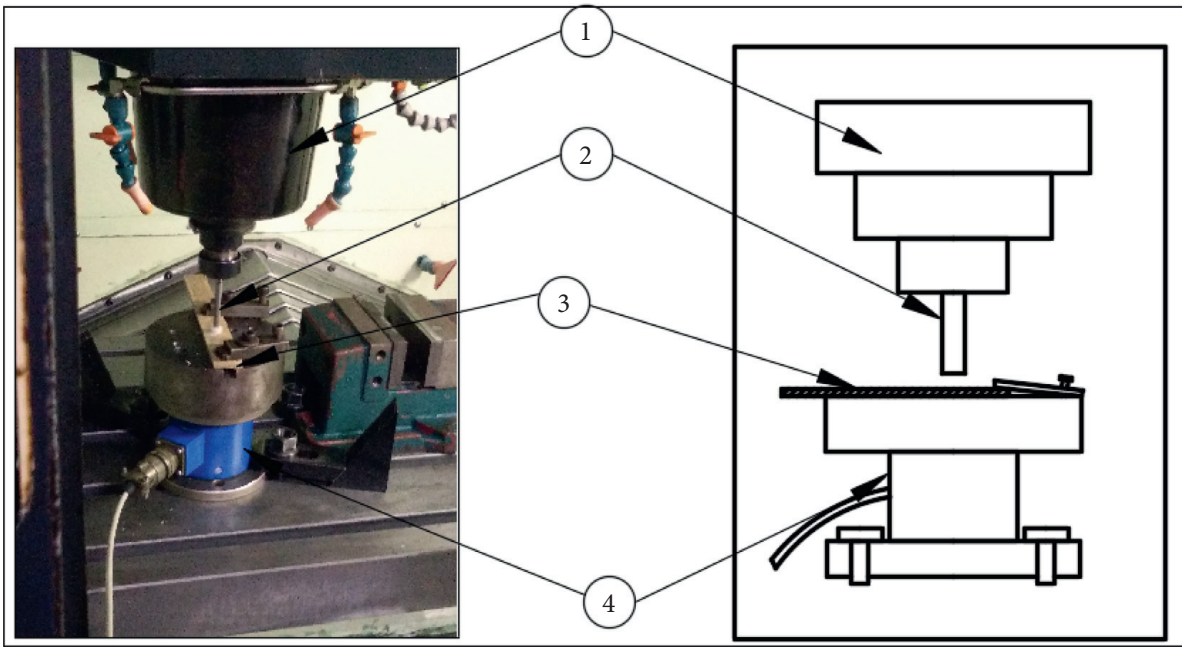

Figure 1: The drilling experimental setup: (1) tool head, (2) drill tool, (3) workpiece, and (4) dynamometer.

TABLE 1: Specification of CNC machine.

Machine tool CNC vertical machining center fitted with acumen high spindle speed

Maximum spindle speed

Required spindle power

$40,000 \mathrm{rpm}$
$5 \mathrm{KW}$

Machine axis

Maximum spindle travel in three axes

Spindle control

3

Tool material

Drill tools

$30 \mathrm{~cm}, 30 \mathrm{~cm}$, and $30 \mathrm{~cm}$

$\mathrm{AC}$ inverter

$0.6 \mathrm{~cm}$ carbide tool

Drilling conditions

$\mathrm{T} 1, \mathrm{~T} 2, \mathrm{~T} 3$, and $\mathrm{T} 4$

Spindle rotational speed $(\mathrm{rpm})$

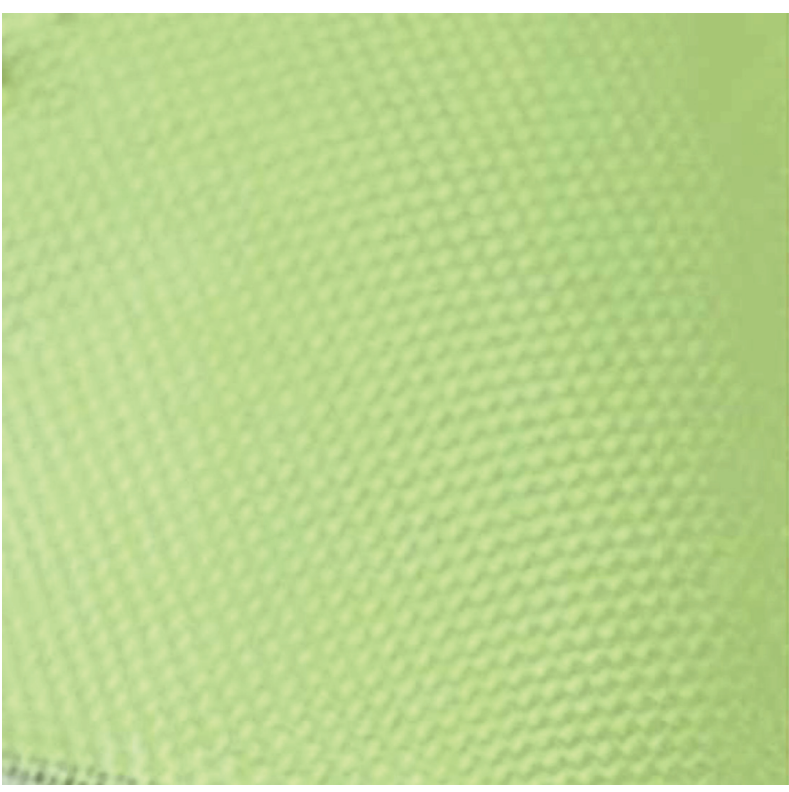

(a)

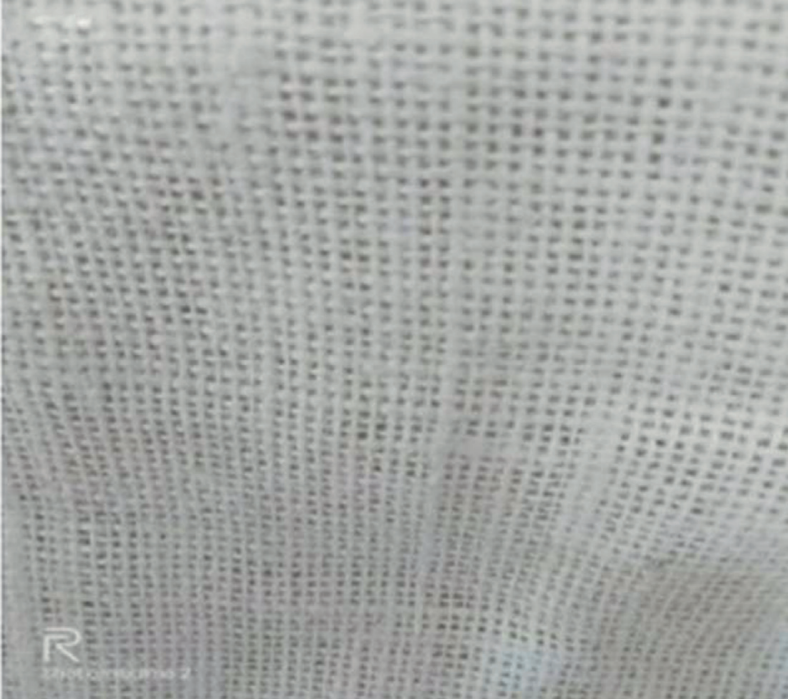

(b)

Figure 2: Woven fabric. (a) Kevlar. (b) Abaca.

$6.25 \%$ higher at $45 \mathrm{~mm} / \mathrm{min}$ compared to the $30 \mathrm{~mm} / \mathrm{min}$ feed rate as shown in Figure 5(b). Likewise, for T3 and at $1000 \mathrm{rpm}$, the thrust force increases $6.49 \%$ more at $45 \mathrm{~mm} /$ min compared to the $30 \mathrm{~mm} / \mathrm{min}$ feed rate as shown in Figure 5(c). For T4 and at $1000 \mathrm{rpm}$, the thrust force increases $8.02 \%$ more at $45 \mathrm{~mm} / \mathrm{min}$ compared to the $30 \mathrm{~mm} /$ 


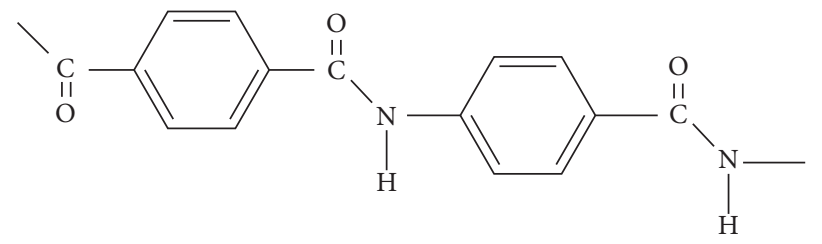

Figure 3: Structure of Kevlar.

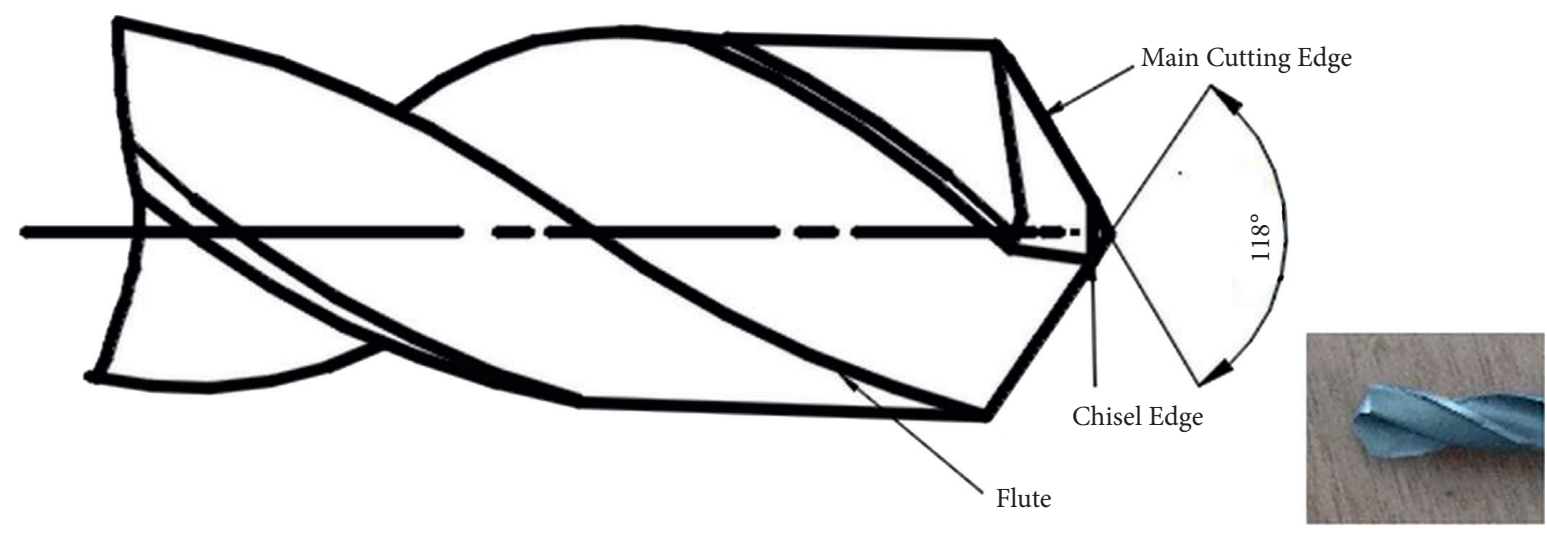

(a)

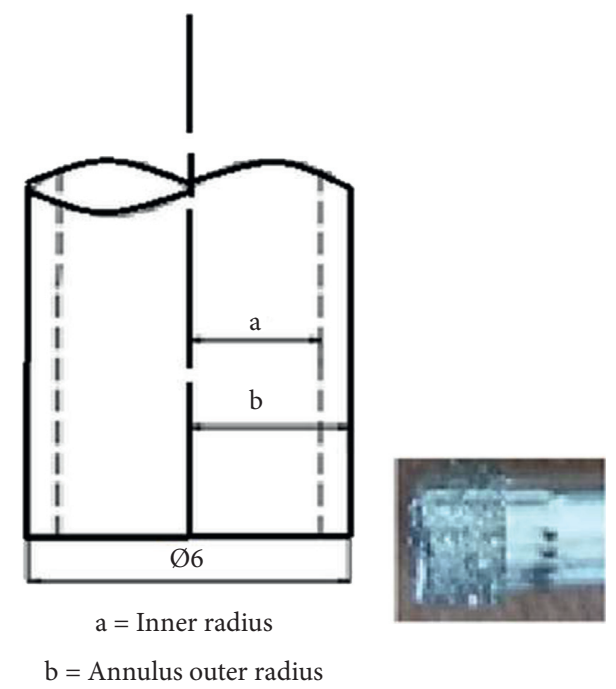

(b)

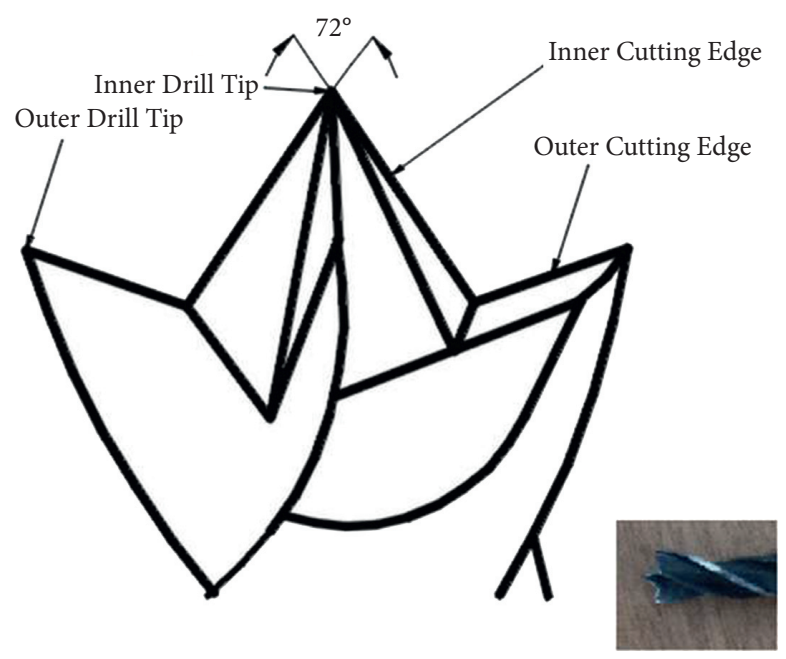

(c)

Figure 4: Continued. 


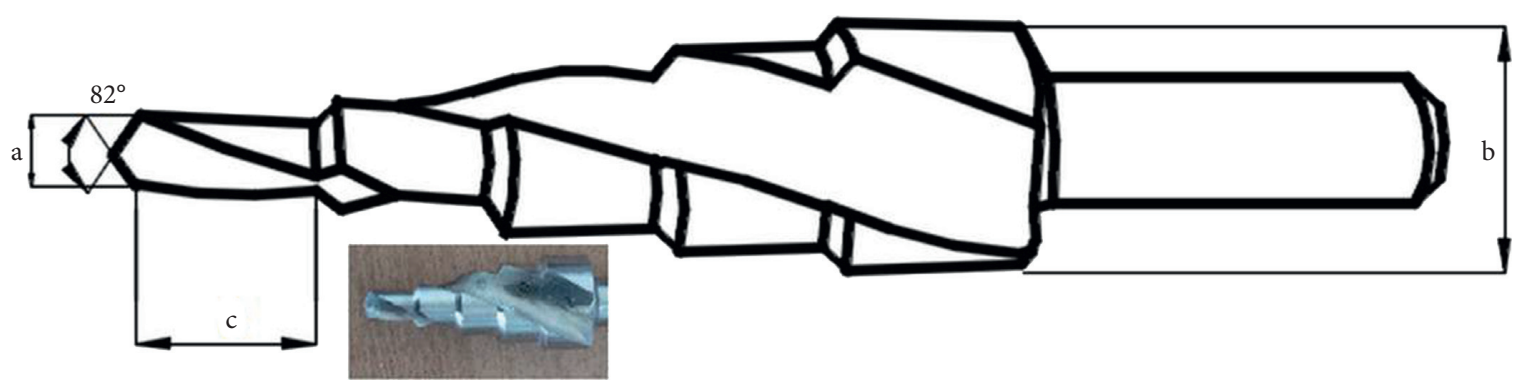

(d)

Figure 4: Different geometries of drill tool, namely, (a) T3, (b) T2, (c) T1, and (d) T4.

TABLE 2: Three levels of speed and feed.

\begin{tabular}{lccc}
\hline Drilling variables & \multicolumn{3}{c}{ Levels } \\
& 1 & 2 & 3 \\
\hline Tool feed $(\mathrm{mm} / \mathrm{min})$ & 30 & 45 & 60 \\
Rotational speed $(\mathrm{rpm})$ & 1000 & 1500 & 2000 \\
Drill diameter $(\mathrm{mm})$ & \multicolumn{3}{c}{ T1, T2, T3, and T4 } \\
Tool type & \multicolumn{3}{c}{6} \\
\hline
\end{tabular}

min feed rate as shown in Figure 5(d). The same trend has been followed for the $60 \mathrm{~mm} / \mathrm{min}$ feed rate and for all the drill bits.

Figure 5 displays that the cutting tool T1 produces lower thrust force compared to T2, T3, and T4 drill tools at $1000 \mathrm{rpm}$ rotational speed and $30 \mathrm{~mm} / \mathrm{min}$ tool feed by all the four drill bits. For T1 tool and at the $30 \mathrm{~mm} / \mathrm{min}$, the thrust force increases to $1.57 \%$ and $3.15 \%$ corresponding to the spindle speed of $1500 \mathrm{rpm}$ and $2000 \mathrm{rpm}$ respectively, compared to 1000 rpm in Figure 5(a). Similar trend has been followed for the T2 tool and at $30 \mathrm{~mm} / \mathrm{min}$, the thrust force is rises to $0.4 \%$ and $0.79 \%$ with the spindle speed of $1500 \mathrm{rpm}$ and $2000 \mathrm{rpm}$ respectively, compared to the $1000 \mathrm{rpm}$ shown in Figure 5(b). Likewise, for the T3 tool and at the $30 \mathrm{~mm} / \mathrm{min}$, the thrust force increases $1.94 \%$ and $3.24 \%$ at $1500 \mathrm{rpm}$ and the $2000 \mathrm{rpm}$, respectively, compared to $1000 \mathrm{rpm}$ as shown in Figure 5(c). For T4 and at $30 \mathrm{~mm} / \mathrm{min}$, the thrust force generates $1.23 \%$ and $1.85 \%$ more at $1500 \mathrm{rpm}$ and $2000 \mathrm{rpm}$, respectively, compared to the minimum spindle speed as shown in Figure 5(d). The thrust force produced by the drill tools, namely, T1, T2, T3, and T4, is minimum at a lower spindle speed and feed rate. If the spindle speed and feed rate increase, thrust force also increases; however, spindle speed influences the thrust force which is minimum compared to the feed rate. The axial force consecutively grows with speed and tool feed. However, the minimal axial force is inferred for T1 followed by T2, T3, and T4 drill tools. It is accorded to the distribution of thrust force around the periphery (T1 and T2 drill bits), whereas the axial force is concentrated at the center of the tool in the case of T3 and T4 drill tools [33, 34].

The contribution of the feed rate and spindle speed on the thrust force is $96.14 \%$ and $2.89 \%$, respectively, during drilling by $\mathrm{T} 1$. Likewise, for $\mathrm{T} 2$, the influence of rotational speed and tool feed on the thrust force is $1.45 \%$ and $98.09 \%$, respectively. The same trend has been followed for the T3 and T4 as shown in Table 3. The spindle speed contribution on the thrust force is very minimal compared to the feed rate as shown in Table 4. There is no dominant variation in thrust force for the range of the variation of rotational speed [38]. Most of the authors reported that there is no significant influence of the rotational speed on the thrust force at the lower range of the spindle speed [37, 39-42]. Abrao et al. [43] reported that the cutting speed influence on the thrust force is negligible and the three cutting edge tools produce higher thrust force with higher cutting speed. In this work, the considered range of spindle speed $(1000 \mathrm{rpm}, 1500 \mathrm{rpm}$, and $2000 \mathrm{rpm}$ ) which contributes to the thrust force is very negligible. However, the thrust force variation due to the spindle speed is not in direct relationship with the delamination [43].

\subsection{Effect of Different Drill Geometries on Axial Force during} Drilling of AFRP Composite. Figure 6 illustrates the thrust force produced by the drill tools, namely, T1, T2, T3, and T4 drill bits, with different feed and speed. Axial force simultaneously increases with rotational speed and tool feed; however, the least thrust force is inferred for $\mathrm{T} 1$ followed by T2, T3, and T4 drill bits. This can be conferred to the distribution of thrust force around the periphery (T3 and T4 drill bits) while the axial force is concentrated at the center of the tool in the case of T3 and T4 drill tools [33]. Figure 6 shows that the thrust force increases with an increase in the feed rate for all the drill bits. For $\mathrm{T} 1$ and at $1000 \mathrm{rpm}$, the thrust force increases $38.18 \%$ more at $45 \mathrm{~mm} / \mathrm{min}$ compared to the $30 \mathrm{~mm} / \mathrm{min}$ feed rate as shown in Figure 6(a). Similarly, the same trend is followed for T2 and at $1000 \mathrm{rpm}$; the thrust force rises $33.92 \%$ higher at $45 \mathrm{~mm} / \mathrm{min}$ compared to the $30 \mathrm{~mm} / \mathrm{min}$ feed rate as shown in Figure 6(b). Likewise, for T3 and at $1000 \mathrm{rpm}$, the thrust force increases $21.05 \%$ more at $45 \mathrm{~mm} / \mathrm{min}$ compared to the $30 \mathrm{~mm} / \mathrm{min}$ feed rate as shown in Figure 6(c). For T4 and at $1000 \mathrm{rpm}$, the thrust force increases $17.07 \%$ more at $45 \mathrm{~mm} / \mathrm{min}$ compared to the $30 \mathrm{~mm} / \mathrm{min}$ feed rate as shown in Figure 6(d). The same trend has been followed for the $60 \mathrm{~mm} / \mathrm{min}$ feed rate and for all the drill bits. The influence of the feed rate on the thrust force during drilling of abaca-based composite is higher compared to the thrust force produced by the drill bits during drilling of Kevlar-reinforced fiber composites due to the properties difference. Figure 6 shows that the drill bit T1 


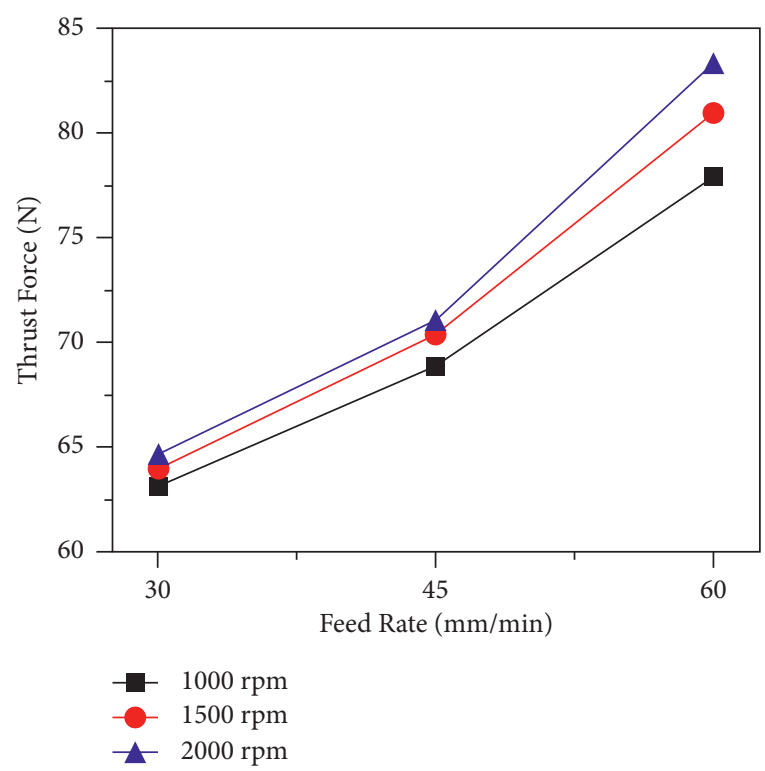

(a)

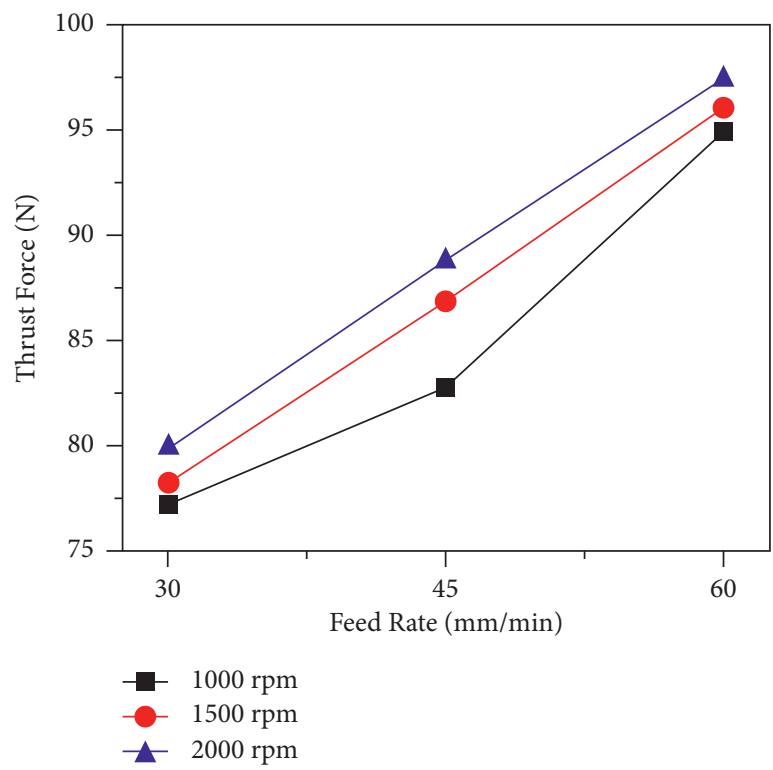

(c)

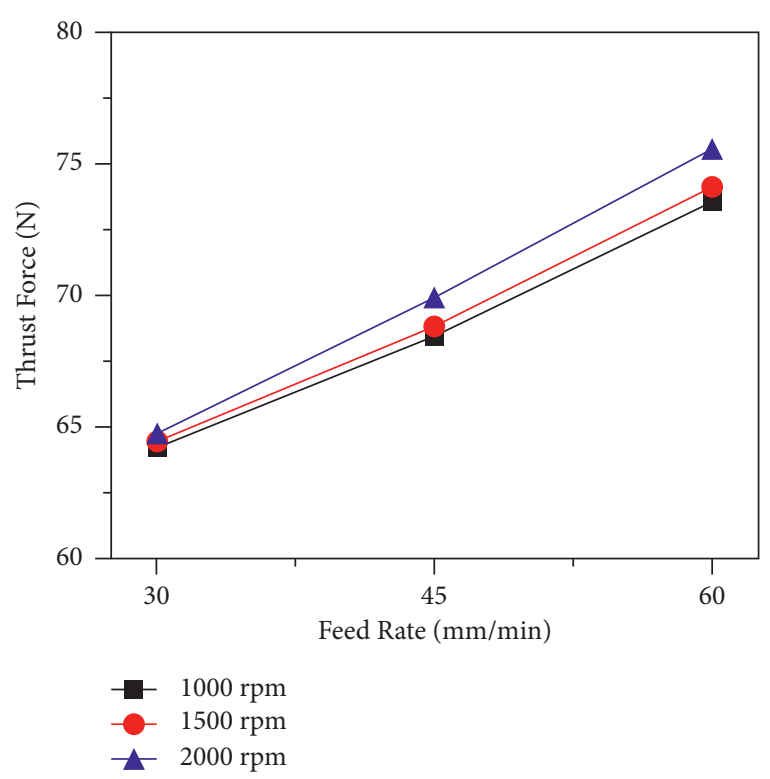

(b)

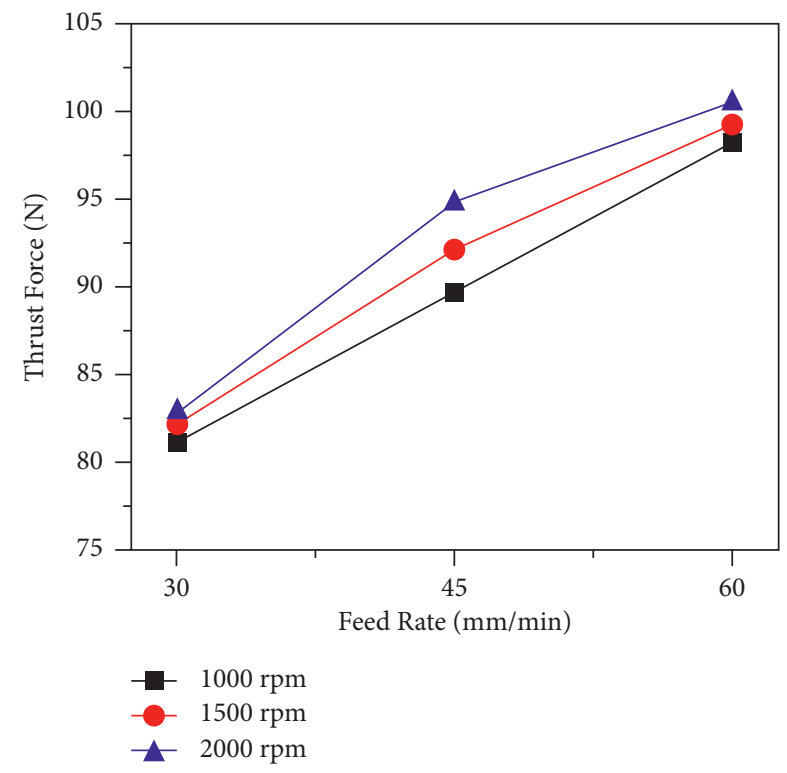

(d)

FIgURE 5: The axial force produced by the drills, namely, (a) T1, (b) T2, (c) T3, and (d) T4 drill tools in KFRP.

produces lower thrust force compared to $\mathrm{T} 2$, $\mathrm{T} 3$, and $\mathrm{T} 4$ drill tools at $1000 \mathrm{rpm}$ rotational speed and $30 \mathrm{~mm} / \mathrm{min}$ tool feed by all the four drill bits for abaca-based composites. For T1 and at $30 \mathrm{~mm} / \mathrm{min}$, the thrust force increases to $0.9 \%$ and $12.72 \%$ with the spindle speed of $1500 \mathrm{rpm}$ and $2000 \mathrm{rpm}$ respectively, compared to the $1000 \mathrm{rpm}$ shown in Figure 6(a). The thrust force is increases the $3.14 \%$ and $7.14 \%$ corresponds to the rpm 1500 and 2000 compared to the Figure 6(b). Likewise, for the $\mathrm{T} 3$ tool and at the $30 \mathrm{~mm} / \mathrm{min}$, the thrust force increases $10.52 \%$ and $13.15 \%$ at $1500 \mathrm{rpm}$ and $2000 \mathrm{rpm}$, respectively, compared to $1000 \mathrm{rpm}$ as shown in Figure 6(c). For T4 and at $30 \mathrm{~mm} / \mathrm{min}$, the thrust force generates $6.17 \%$ and $8.64 \%$ more at $1500 \mathrm{rpm}$ and $2000 \mathrm{rpm}$, respectively, compared to the minimum spindle speed as shown in Figure 6(d). The thrust force produced by the drill tools, namely, T1, T2, T3, and T4, is minimum at a lower spindle speed and feed rate. If the spindle speed and feed rate increase, thrust force also increases; however, spindle speed influences the thrust force is minimum compared to the feed rate.

In the same way of Kevlar-based composites, the spindle speed of abaca-based composite contribution on the thrust force is very lesser compared to the feed rate as shown in Table 5. The contribution of the tool feed and rotational speed on the thrust force is $94.22 \%$ and $4.91 \%$, respectively, during drilling by T1. Likewise, for T2, the influence of rotational speed and tool feed on the thrust force is 3.42\% and $96.03 \%$, respectively. In the same way of Kevlar-based composite, the 
TABLE 3: Thrust force generated by different geometrical drills.

\begin{tabular}{l} 
Drill \\
geometry \\
\hline
\end{tabular} $\begin{aligned} & \text { Thao and Hocheng [35] reported that the critical thrust force of the candlestick drill varies corresponding to the } \alpha \text { value; } \alpha \text { is } \\
& \text { the ratio of critical thrust force generated by the candlestick with an outer moment and without outer moment. According } \\
& \text { to the theoretical result, the total thrust force increases with an } \alpha \text { value up to } 0.85 \text { and then decreases; the increase of the } \\
& \text { Poisson's ratio of the drill tool also contributes towards higher thrust force. In this work, T1 has three outer edges; hence, } \\
& \text { the moment distributed on the outer of the drilling surface is higher, and it may be the reason for the lower thrust force } \\
& \text { T1 } \\
& \text { Tsalue. } \\
& \text { theoretically, in which the ratio of with and without moment created on the outer surfaces is taken as } \beta \text {. The theoretical } \\
& \text { critical thrust force value decreases when the } \beta \text { value lies between } 0 \text { to 0.6. In this work, the T2 has multicutting edges on the } \\
& \text { outer surfaces; the moment distributed by the T2 on the outer surfaces is higher. Hence, this may be the reason for the lower } \\
& \text { critical thrust force. } \\
& \text { T2 Hocheng and Tsao [36] proposed a mathematical model for the critical thrust force during drilling of fiber-based } \\
& \text { composites by using a standard twist drill. They categorized drilling using the standard twist drill as concentrated central } \\
& \text { load. They also reported that the ratio of the radius of twist drill to the width of uncut thickness close to the value } 1 \\
& \text { generates very high critical thrust force. In this work, the twist drill generates a combination of twist and downward thrust } \\
& \text { force [37], which creates more thrust force compared to T1 and T2, which may be the reason for higher thrust force. } \\
& \text { Hocheng and Tsao [33] reported that the critical thrust force generated during the drilling of fiber-based composite by step } \\
& \text { drill is close to the standard twist drill. The critical thrust force generated in the step drill consists of two stages, namely, } \\
& \text { primary and secondary stages. The critical thrust force is generated predominately in the secondary cutting lips of the step } \\
& \text { drill. In this work, the central concentrated load combined with the twisting moment acting on the uncut thickness of the } \\
& \text { bottom of the composite specimen may be the reason for higher thrust force. }\end{aligned}$

TABLE 4: ANOVA results for thrust force produced by drill bits in Kevlar-reinforced epoxy resin.

\begin{tabular}{|c|c|c|c|c|c|c|}
\hline Source & $\begin{array}{c}\text { Sum square error } \\
\text { (SSE) }\end{array}$ & $\begin{array}{c}\text { Degree of freedom } \\
(\mathrm{DOF})\end{array}$ & $\begin{array}{c}\text { Mean square error } \\
\text { (MSE) }\end{array}$ & $\begin{array}{c}\text { F- } \\
\text { statistics }\end{array}$ & $\begin{array}{c}\mathrm{P}- \\
\text { statistics }\end{array}$ & $\begin{array}{c}\text { Percentage of contribution } \\
(\mathrm{P})\end{array}$ \\
\hline \multicolumn{7}{|l|}{$\overline{\mathrm{T} 1}$} \\
\hline $\begin{array}{l}\text { Rotational } \\
\text { speed }\end{array}$ & 13.021 & 2 & 6.510 & 5.99 & 0.043 & 2.89 \\
\hline$(\mathrm{N}) \mathrm{rpm}$ & 432.792 & 2 & 216.396 & 198.94 & $p \leq 0.01$ & 96.14 \\
\hline Tool rate (f) & 4.351 & 4 & 1.088 & - & - & 0.97 \\
\hline $\mathrm{mm} / \mathrm{min}$ & 450.164 & 8 & - & & & \\
\hline \multicolumn{7}{|l|}{ Error } \\
\hline \multicolumn{7}{|l|}{ Total } \\
\hline \multicolumn{7}{|l|}{$\mathrm{T} 2$} \\
\hline $\begin{array}{l}\text { Rotational } \\
\text { speed }\end{array}$ & 2.221 & 2 & 1.1107 & 6.59 & 0.044 & 1.45 \\
\hline (N) rpm & 149.455 & 2 & 74.7277 & 443.28 & $p \leq 0.01$ & 98.09 \\
\hline Tool rate (f) & 0.674 & 4 & 0.1686 & - & - & 0.44 \\
\hline $\mathrm{mm} / \mathrm{min}$ & 152.351 & 8 & - & & & \\
\hline \multicolumn{7}{|l|}{ Error } \\
\hline \multicolumn{7}{|l|}{ Total } \\
\hline \multicolumn{7}{|l|}{$\mathrm{T} 3$} \\
\hline $\begin{array}{l}\text { Rotational } \\
\text { speed }\end{array}$ & 20.84 & 2 & 10.423 & 9.28 & 0.031 & 4.18 \\
\hline$(\mathrm{N}) \mathrm{rpm}$ & 472.289 & 2 & 236.145 & 210.18 & $p \leq 0.01$ & 94.90 \\
\hline Tool rate (f) & 4.494 & 4 & 1.124 & - & - & 0.90 \\
\hline $\mathrm{mm} / \mathrm{min}$ & 497.629 & 8 & - & & & \\
\hline \multicolumn{7}{|l|}{ Error } \\
\hline \multicolumn{7}{|l|}{ Total } \\
\hline \multicolumn{7}{|l|}{$\mathrm{T} 4$} \\
\hline $\begin{array}{l}\text { Rotational } \\
\text { speed }\end{array}$ & 13.98 & 2 & 6.993 & 7.98 & 0.040 & 2.97 \\
\hline (N) rpm & 451.82 & 2 & 225.914 & 257.95 & $p \leq 0.01$ & 96.27 \\
\hline Tool rate (f) & 3.503 & 4 & 0.876 & - & - & 0.746 \\
\hline $\mathrm{mm} / \mathrm{min}$ & 469.317 & 8 & - & & & \\
\hline \multicolumn{7}{|l|}{ Error } \\
\hline Total & & & & & & \\
\hline
\end{tabular}




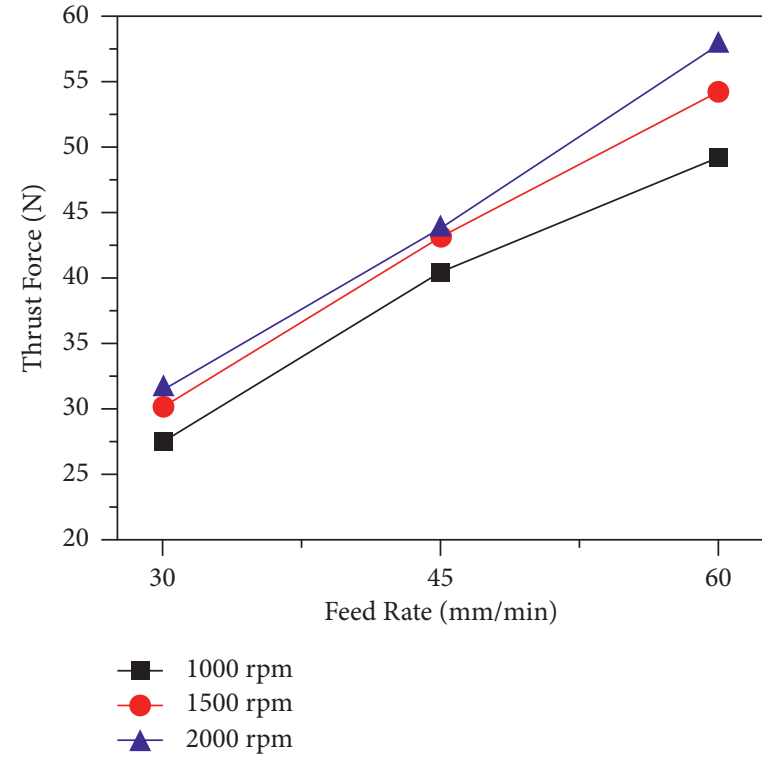

(a)

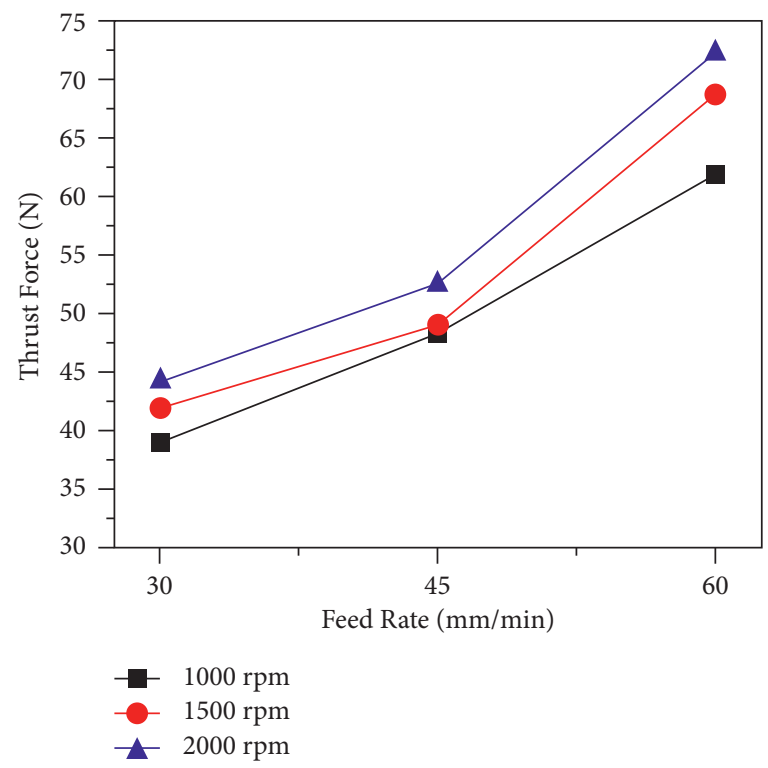

(c)

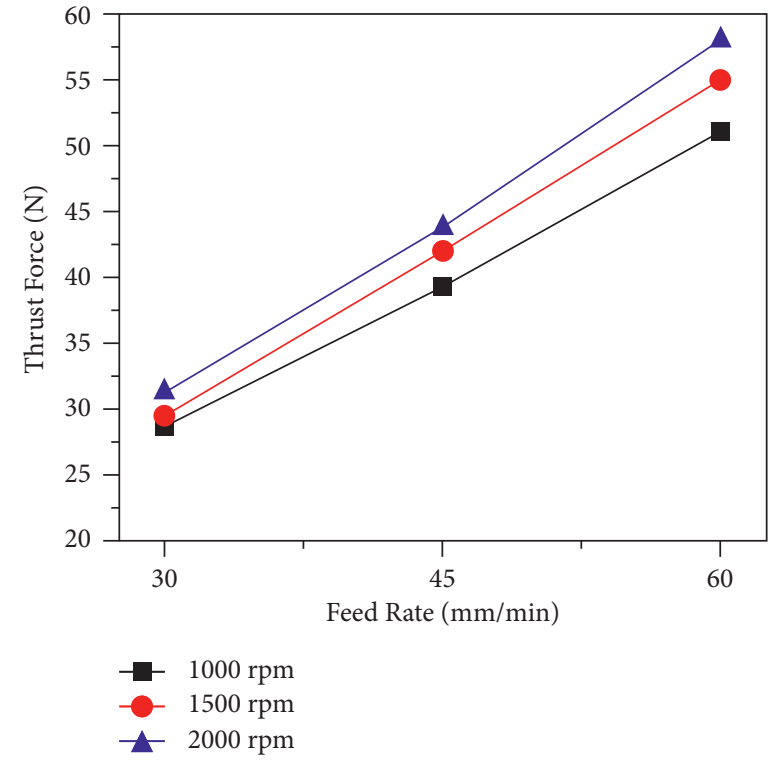

(b)

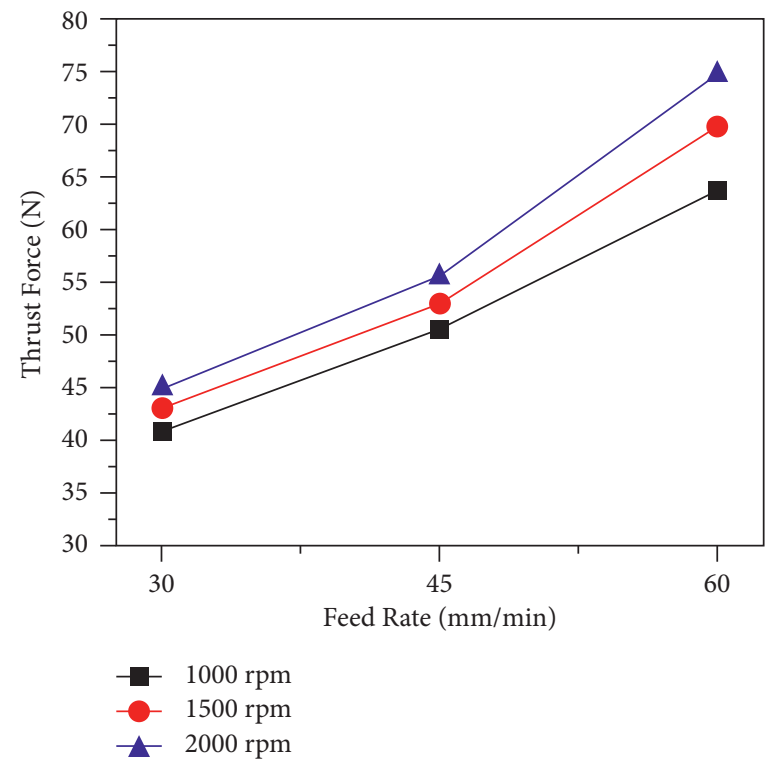

(d)

Figure 6: The thrust force generated by the drills, namely, (a) T1, (b) T2, (c) T3, and (d) T4 drill tools in AFRP.

trend has been followed for the T3 and T4 as shown in Table 5. There is no dominant variation in thrust force for the range of the variation of spindle speed [38]. Most of the authors reported that there is no significant effect of the spindle speed on the thrust force at the lower range of the spindle speed $[37,39-42]$. The cutting speed influenced on the thrust force is negligible and the three cutting edge tools produce higher thrust force with higher cutting speed; the range of the thrust force has varied for natural and synthetic behaviour due to the property differences. The thrust force is negligible for the certain spindle speed. However, the thrust force variation due to the spindle speed is not in direct relationship with the delamination [43].
3.3. Thrust Force Generated by the Special Drill Geometries. The thrust force generated by the different drill bit geometries is listed in Table 3. The comparison of the previous studies of thrust force generated during drilling of fiberbased composites by different geometries with the present work is given in Table 3.

The axial force generated by the $\mathrm{T} 1$ drill on abaca and Kevlar-based composites is shown in Figure 7. At $1000 \mathrm{rpm}$ rotational speed and three different feed rates, the drilling has been carried out in abaca and Kevlar-reinforced epoxy composites. A similar trend is followed in both cases and the thrust force produced is minimal at specified rotational speed and tool feed which are $1000 \mathrm{rpm}$ and $30 \mathrm{~mm} / \mathrm{min}$, 
TABLE 5: ANOVA results for axial force produced by drill bits in abaca-reinforced epoxy resin.

\begin{tabular}{|c|c|c|c|c|c|c|}
\hline Source & $\begin{array}{c}\text { Sum square error } \\
\text { (SSE) }\end{array}$ & $\begin{array}{l}\text { Degree of freedom } \\
\text { (DOF) }\end{array}$ & $\begin{array}{c}\text { Mean square error } \\
\text { (MSE) }\end{array}$ & $\begin{array}{c}\text { F- } \\
\text { statistics }\end{array}$ & $\begin{array}{c}\mathrm{P}- \\
\text { statistics }\end{array}$ & $\begin{array}{l}\text { Percentage of } \\
\text { contribution } \\
(\mathrm{P})\end{array}$ \\
\hline \multicolumn{7}{|l|}{$\mathrm{T} 1$} \\
\hline Rotational speed (N) & 44.91 & 2 & 22.458 & 11.55 & 0.022 & 4.91 \\
\hline $\mathrm{rpm}$ & 6 & 2 & 430.191 & 221.24 & $p \leq 0.01$ & 94.22 \\
\hline $\begin{array}{l}\text { Tool rate }(\mathrm{f}) \mathrm{mm} / \\
\min \end{array}$ & 860.3 & 4 & 1.944 & - & - & 0.85 \\
\hline Error & 82 & 8 & - & & & \\
\hline Total & $\begin{array}{c}7.778 \\
913.0 \\
76 \\
\end{array}$ & & & & & \\
\hline \multicolumn{7}{|l|}{$\overline{\mathrm{T} 2}$} \\
\hline Rotational speed (N) & 33.20 & 2 & 16.601 & 12.74 & 0.018 & 3.42 \\
\hline $\mathrm{rpm}$ & 2 & 2 & 465.274 & 357.14 & $p \leq 0.01$ & 96.03 \\
\hline $\begin{array}{l}\text { Tool rate }(\mathrm{f}) \mathrm{mm} / \\
\mathrm{min}\end{array}$ & 930.5 & 4 & 1.303 & - & - & 0.54 \\
\hline Error & $\begin{array}{c}49 \\
5.211\end{array}$ & 8 & - & & & \\
\hline Total & $\begin{array}{c}968.9 \\
62 \\
\end{array}$ & & & & & \\
\hline \multicolumn{7}{|l|}{ T3 } \\
\hline Rotational speed (N) & 66.07 & 2 & 33.034 & 9.87 & 0.028 & 5.82 \\
\hline $\mathrm{rpm}$ & 1054 & 2 & 527.124 & 157.46 & $p \leq 0.01$ & 92.99 \\
\hline $\begin{array}{l}\text { Tool rate }(\mathrm{f}) \mathrm{mm} / \\
\text { min }\end{array}$ & 25 & 4 & 3.348 & - & - & 1.18 \\
\hline Error & 13.39 & 8 & - & & & \\
\hline Total & $\begin{array}{c}1133 . \\
71\end{array}$ & & & & & \\
\hline \multicolumn{7}{|l|}{$\mathrm{T} 4$} \\
\hline Rotational speed (N) & 68.75 & 2 & 34.374 & 9.09 & 0.033 & 5.97 \\
\hline $\mathrm{rpm}$ & 1067. & 2 & 533.754 & 141.16 & $p \leq 0.01$ & 92.71 \\
\hline $\begin{array}{l}\text { Tool rate }(\mathrm{f}) \mathrm{mm} / \\
\text { min }\end{array}$ & 51 & 4 & 3.781 & - & - & 1.31 \\
\hline Error & 15.12 & 8 & - & & & \\
\hline Total & $\begin{array}{c}1151 . \\
38\end{array}$ & & & & & \\
\hline
\end{tabular}

respectively. However, the range of thrust force of Kevlar is higher owing to the fiber strength.

Defects at drill entry during drilling of abaca- and Kevlarbased composite are shown in Figure 8. The drilling has been performed by candlestick drill tool at $1000 \mathrm{rpm}$ spindle speed and different feed rates. In Figure 8, A1, A2, and A3 refer to the drilling of the abaca-based composite at $30 \mathrm{~mm} / \mathrm{min}$, $45 \mathrm{~mm} / \mathrm{min}$, and $60 \mathrm{~mm} / \mathrm{min}$, respectively. Similarly, K1, K2, and $\mathrm{K} 3$ denote drilling of Kevlar-based composite at $30 \mathrm{~mm} /$ $\mathrm{min}, 45 \mathrm{~mm} / \mathrm{min}$, and $60 \mathrm{~mm} / \mathrm{min}$, respectively. Figure 6 shows that the drilling defects at the entry of A1 are lesser compared to A2 and A3 due to the lesser thrust force shown in Figure 8 (abaca). Similarly, the defect of $\mathrm{K} 1$ is lesser compared to $\mathrm{K} 2$ and $\mathrm{K} 3$ due to lesser thrust force as shown in Figure 8 (Kevlar). However, the drilling defect of $\mathrm{K} 1$ is very much higher compared to A1 due to the difference in thrust force.

3.4. Optimization of Drilling Process Parameters of Kevlar and Abaca Fiber-Reinforced Epoxy Composite Using Rotational Speed and Tool Feed. This study is necessary to find the percentage contribution of drilling variables on the axial force. Table 2 displays three levels of speed and tool feed. Tables 4 and 5 show ANOVA results for axial force produced by drill bits in KFRP and AFRP composites, respectively, using Taguchi L9 orthogonal array. The percentage of the impact of tool feed is quite high compared to spindle speed and error associated.

Table 4 depicts ANOVA results for thrust force produced by drill bits using Taguchi L9 orthogonal array. The percentage of the impact of tool feed and rotational speed is high compared to associated error. The T1, T2, T3, and T4 drill tools display $96.14 \%, 98.09 \%, 94.90 \%$, and $96.27 \%$ of the contribution of feed rate towards axial force. It is revealed that tool feed and spindle speed have potential physical and statistical importance on torque compared to associated error [44]. In the same way, Table 5 shows ANOVA results for axial force produced by drill bits using Taguchi L9 orthogonal array. The percentage of the impact of tool feed is very high compared to rotational speed and error associated.

The T1, T2, T3, and T4 display $94.22 \%, 96.03 \%, 92.99 \%$, and $92.71 \%$ of the impact of tool feed towards thrust force. 


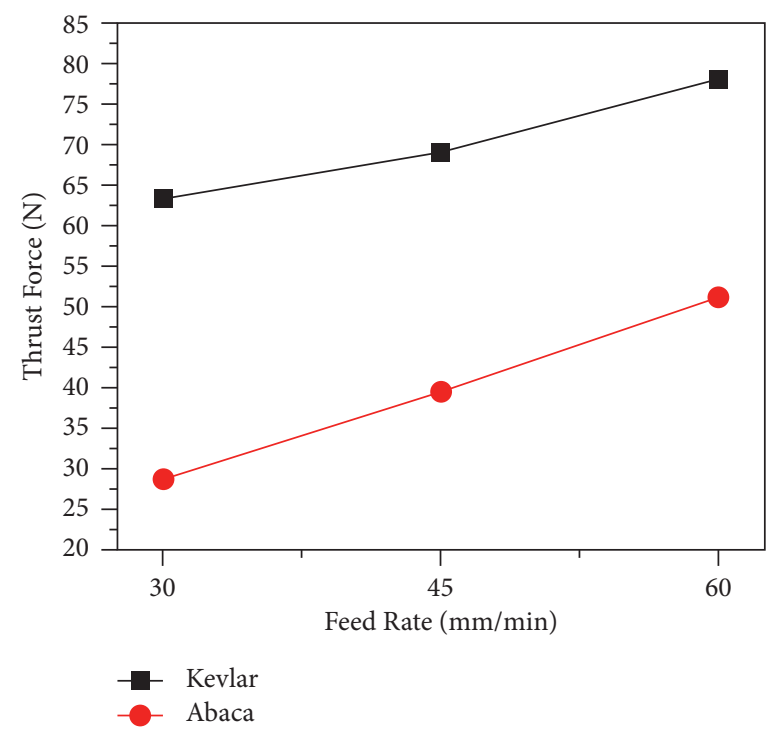

Figure 7: Thrust force generated by T1 drill bit in abaca and Kevlar-reinforced epoxy composites.
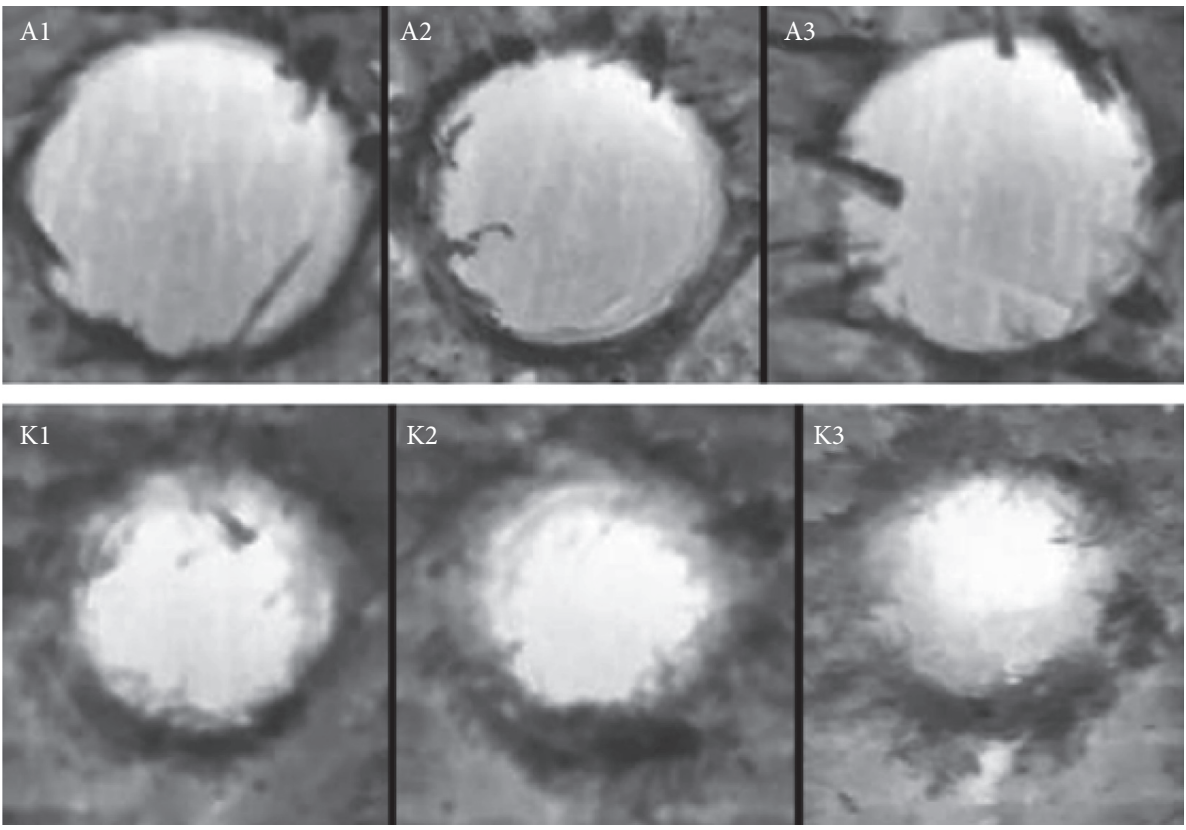

Figure 8: Defect at hole entry of abaca (A1, A2, and A3) and Kevlar (K1, K2, and K3).

This infers that the feed rate has physical and statistical prominence on thrust compared to spindle speed and associated error [44].

\section{Conclusion}

The thrust force produced by T1 and T2 drill tools is minimal compared to other drill tools. At minimal rotational speed and tool feed, $28.6 \mathrm{~N}$ of thrust force was obtained during drilling in abaca-based composites. Similarly, $63.18 \mathrm{~N}$ of thrust force has been attained while drilling Kevlar-based composites. The strong physical interaction of fiber and matrix and thrust force dispersed around the circumferential of the drill may be responsible for minimum thrust force.
For abaca, the contribution of tool feed on the axial force for T3, T2, T4, and T1 drill bits is $92.99 \%, 92.71 \%, 98.97 \%$, and $94.22 \%$, respectively. Likewise, the impact of spindle speed on thrust force of $\mathrm{T} 3, \mathrm{~T} 2, \mathrm{~T} 4$, and $\mathrm{T} 1$ drills bits is $5.82 \%$, $3.42 \%, 5.97 \%$, and $4.91 \%$, respectively. It implies that the tool feed has strong statistical and physical importance. The same trend is followed for abaca-reinforced epoxy composites. Hence, it is evident that $\mathrm{T} 1$ and $\mathrm{T} 2$ drill bits are appropriate for drilling abaca and Kevlar-reinforced epoxy resin.

\section{Data Availability}

The data used to support the findings of this study are included within the article. 


\section{Conflicts of Interest}

The authors declare that there are no conflicts of interest regarding the publication of this article.

\section{References}

[1] Y. He, X. Zhou, P. Zou, and K. Liu, "Study of complex helical drill with a " $\mathrm{S}$ " type chisel edge tip orient to carbon fiber reinforced plastics," Advances in Materials Science and Engineering, vol. 2021, Article ID 5175515, 14 pages, 2021.

[2] H. Hocheng and C. C. Tsao, "The path towards delaminationfree drilling of composite materials," Journal of Materials Processing Technology, vol. 167, no. 2-3, pp. 251-264, 2005.

[3] D. Bhattacharyya and D. P. W. Horrigan, "A study of hole drilling in Kevlar composites," Composites Science and Technology, vol. 58, no. 2, pp. 267-283, 1998.

[4] C. C. Tsao and H. Hocheng, "Taguchi analysis of delamination associated with various drill bits in drilling of composite material," International Journal of Machine Tools and Manufacture, vol. 44, no. 10, pp. 1085-1090, 2004.

[5] M.-I. Kim and P. Zou, "Modeling of drilling forces based on twist drill point angles using multigene genetic programming," Mathematical Problems in Engineering, vol. 2016, Article ID 6749182, 9 pages, 2016.

[6] I. Singh, N. Bhatnagar, and P. Viswanath, "Drilling of unidirectional glass fiber reinforced plastics: experimental and finite element study," Materials \& Design, vol. 29, no. 2, pp. 546-553, 2008.

[7] Y. Bao, Y. Zhang, H. Gao, and X. Liu, "Temperature field study of hole drilling in kevlar composites," Advanced Materials Research, vol. 806, 2015.

[8] P. V. S. Teja, S. Prakash, B. N. Prasad, and G. Elijah, "Finite element analysis in drilling GFRP composites," Indian Journal of Science and Technology, vol. 8, 2015.

[9] J. Babu, T. Sunny, J. Philip, and S. K. Bhullar, "A digital image analysis to evaluate delamination factor after drilling GFRP composites using a kevlar drill bit," Indian Journal of Science and Technology, vol. 9, 2016.

[10] S. O. Ismail, S. O. Ojo, and H. N. Dhakal, "Thermo-mechanical modelling of FRP cross-ply composite laminates drilling: delamination damage analysis," Composites Part B: Engineering, vol. 108, pp. 45-52, 2017.

[11] U. Köklü, O. Demir, A. Avcı, and A. Etyemez, "Drilling performance of functionally graded composite: comparison with glass and carbon/epoxy composites," Journal of Mechanical Science and Technology, vol. 31, no. 10, pp. 4703-4709, 2017.

[12] K. Giasin and S. Ayvar-Soberanis, "Microstructural investigation of drilling induced damage in fibre metal laminates constituents," Composites Part A: Applied Science and Manufacturing, vol. 97, pp. 166-178, 2017.

[13] M. Bosco, K. Palanikumar, B. D. Prasad, and A. Velayudham, "Analysis on influence of machining parameters on thrust force in drilling GFRP-armor steel sandwich composites," Journal of Composite Materials, vol. 49, no. 13, pp. 1539-1551, 2015.

[14] N. Zarif Karimi, G. Minak, and P. Kianfar, "Analysis of damage mechanisms in drilling of composite materials by acoustic emission," Composite Structures, vol. 131, pp. 107-114, 2015.

[15] T. J. Singh and S. Samanta, "Multi-response parametric optimization in drilling of bamboo/Kevlar fiber reinforced sandwich composite," IOP Conference Series: Materials Science and Engineering, IOP Publishing, vol. 149, Article ID 012028, 2016.
[16] P. K. Bajpai, K. Debnath, and I. Singh, "Hole making in natural fiber-reinforced polylactic acid laminates," Journal of Thermoplastic Composite Materials, vol. 30, no. 1, pp. 30-46, 2017.

[17] M. P. N. E. Naveen, M. Yasaswi, and R. Prasad, "Experimental investigation of drilling parameters on composite materials," IOSR Journal of Mechanical and Civil Engineering, vol. 2, no. 3, pp. 30-37, 2012.

[18] S. Jayabal and U. Natarajan, "Optimization of thrust force, torque, and tool wear in drilling of coir fiber-reinforced composites using Nelder-Mead and genetic algorithm methods," International Journal of Advanced Manufacturing Technology, vol. 51, no. 1-4, pp. 371-381, 2010.

[19] E. Kilickap, "Optimization of cutting parameters on delamination based on Taguchi method during drilling of GFRP composite," Expert Systems with Applications, vol. 37, no. 8, pp. 6116-6122, 2010.

[20] K. Palanikumar, "Experimental investigation and optimisation in drilling of GFRP composites," Measurement, vol. 44, no. 10 , pp. 2138-2148, 2011.

[21] E. Kilickap, "Modeling and optimization of burr height in drilling of Al-7075 using Taguchi method and response surface methodology," International Journal of Advanced Manufacturing Technology, vol. 49, no. 9-12, pp. 911-923, 2010.

[22] R. Çakıroğlu and A. Acır, "Optimization of cutting parameters on drill bit temperature in drilling by Taguchi method," Measurement, vol. 46, pp. 3525-3531, 2013.

[23] V. K. Vankanti and V. Ganta, "Optimization of process parameters in drilling of GFRP composite using Taguchi method," Journal of Materials Research and Technology, vol. 3, no. 1, pp. 35-41, 2014.

[24] J. Prasanna, L. Karunamoorthy, M. Venkat Raman, S. Prashanth, and D. Raj Chordia, "Optimization of process parameters of small hole dry drilling in Ti-6Al-4V using Taguchi and grey relational analysis," Measurement, vol. 48, pp. 346-354, 2014.

[25] N. S. Mohan, S. M. Kulkarni, and A. Ramachandra, "Delamination analysis in drilling process of glass fiber reinforced plastic (GFRP) composite materials," Journal of Materials Processing Technology, vol. 186, no. 1-3, pp. 265-271, 2007.

[26] Y. Chen, Y. Wang, and H. Wang, "Research progress on interlaminar failure behavior of fiber metal laminates," Advances in Polymer Technology, vol. 2020, Article ID 3097839, 20 pages, 2020.

[27] J. Kadolph Sara and A. L. LangfordPrentice-Hall, Textiles, NJ, Hoboken, NJ, US, 2002.

[28] A. D. Bruno and M. Baskaran, "Analysing the mechanical properties of natural fiber reinforced polymer composites using FEA," International Journal of Engineering, Science and Technology, vol. 3, pp. 269-282, 2014.

[29] S. T. Peters, Handbook of Composites, Springer Science \& Business Media, Berlin, Germany, 2013.

[30] M. S. Huda, L. T. Drzal, A. K. Mohanty, and M. Misra, "Effect of fiber surface-treatments on the properties of laminated biocomposites from poly (lactic acid) (PLA) and kenaf fibers," Composites Science and Technology, vol. 68, no. 2, pp. 424-432, 2008.

[31] M. A. J. Bosco, K. Palanikumar, B. D. Prasad, and A. Velayudham, "Influence of machining parameters on delamination in drilling of GFRP-armour steel sandwich composites," Procedia Engineering, vol. 51, pp. 758-763, 2013.

[32] R. Parameshwaran, R. Rajasekar, V. H. Ragavendra, and N. Praveenraj, "Effect of thrust force, torque, and induced 
temperature on Kevlar reinforced composites during drilling process," Materials Today: Proceedings, vol. 45, pp. 522-528, 2021.

[33] H. Hocheng and C. C. Tsao, "Effects of special drill bits on drilling-induced delamination of composite materials," International Journal of Machine Tools and Manufacture, vol. 46, no. 1213, pp. 1403-1416, 2006.

[34] A. M. Kumar, R. Parameshwaran, V. Krishnaraj, and R. Rajasekar, "Effects of thrust force variation during the drilling of pure and chemically treated Kevlar based polymer composites," Materials Testing, vol. 61, no. 9, pp. 907-913, 2019.

[35] C. C. Tsao and H. Hocheng, "Effects of peripheral drilling moment on delamination using special drill bits," Journal of Materials Processing Technology, vol. 201, no. 1-3, pp. 471-476, 2008.

[36] CC. Tsao and H. Hocheng, "Comprehensive analysis of delamination in drilling of composite materials with various drill bits," Journal of Materials Processing Technology, vol. 140, pp. 335-339, 2003.

[37] L. Tan Chye and A. A. Iskandar, "Thrust force analyses in drilling FRP composites," Machining and Machinability of Fiber Reinforced Polymer Composites, pp. 27-62, Springer, Berlin, Germany, 2021.

[38] S. Bayraktar and Y. Turgut, "Investigation of the cutting forces and surface roughness in milling carbon-fiber-reinforced polymer composite material," Materiali in tehnologije, vol. 50, pp. 591-600, 2016.

[39] L. Sorrentino, S. Turchetta, and C. Bellini, "In process monitoring of cutting temperature during the drilling of FRP laminate," Composite Structures, vol. 168, pp. 549-561, 2017.

[40] Ş. Bayraktar and Y. Turgut, "Determination of delamination in drilling of carbon fiber reinforced carbon matrix composites/Al 6013-T651 stacks," Measurement, vol. 154, Article ID 107493, 2020.

[41] A. Hrechuk, V. Bushlya, and J.-E. Ståhl, "Hole-quality evaluation in drilling fiber-reinforced composites," Composite Structures, vol. 204, pp. 378-387, 2018.

[42] S. Bayraktar, "Assessment of cutting performance on drilling with different drilling methods of fiber reinforced polymer composites: a Literature Review," Journal of the Faculty of Engineering and Architecture of Gazi University, vol. 33, pp. 629-647, 2018.

[43] A. M. Abrão, J. C. C. Rubio, P. E. Faria, and J. P. Davim, "The effect of cutting tool geometry on thrust force and delamination when drilling glass fibre reinforced plastic composite," Materials \& Design, vol. 29, no. 2, pp. 508-513, 2008.

[44] V. Krishnaraj, S. Vijayarangan, and G. Suresh, "An investigation on high speed drilling of glass fibre reinforced plastic (GFRP)," Indian Journal of Engineering and Materials Sciences, vol. 12, no. 3, pp. 189-195, 2005. 